\title{
Design and Application of Harmonic Passive Filter
}

\author{
Jeong-Chay Jeon ${ }^{1}$, Jae-Hyun Kim ${ }^{1}$ and Jae-Geun Yoo $^{1^{*}}$ \\ ${ }^{1}$ Korea Electrical Safety Research Institute, KESCO \\ 고조파 수동필터의 설계 및 적용 \\ 전정채 ${ }^{1}$, 김재현 ${ }^{1}$, 유재근 ${ }^{*}$ \\ ${ }^{1}$ 한국전기안전공사 전기안전연구원
}

\begin{abstract}
Accidents involving electric equipment and economical loss by power quality deterioration related to harmonics show a rising tendency A passive filter is economic and efficient in suppressing harmonics but many engineers and designers are reluctant to install a passive filter to defect harmonics at their power system because of problems such as harmonic amplification and the probability of generating series or parallel resonance with the power system. This work introduces that passive filters will be very available to defeat harmonic problems of the power system if passive filters are well designed. We describe method and process of harmonic passive filter design. And the passive filter for the power system having harmonic problems due to use of nonlinear loads like as 100HP DC motor system, an extruding machine, an air blower and other loads are designed. Experimental results verify the performance of the passive filter designed by the described method and procedure.
\end{abstract}

요 약 고조파와 관련한 전력품질저하로 발생하는 전기설비사고 및 경제적 손실은 증가하고 있다. 수동필터는 고조 파 문제를 해결하는데 경제적이고 효과적이지만 많은 엔지니어들은 그들의 전력시스템과의 직병렬 공진 문제 및 고 조파 증폭 문제로 인해 사용하기를 꺼려한다. 본 논문은 수동필터가 잘 설계될 경우 고조파 문제를 해결하는데 매우 유용하다는 것을 보여준다. 고조파 수동필터 설계의 방법과 과정을 서술하였다. 그리고 $100 \mathrm{HP} \mathrm{DC}$ 모터, 압출 기계, 에어 압력기 등과 같은 비선형 부하로 인해 고조파 문제를 갖는 계통에 적용할 수 있는 수동필터를 설계하였다. 제 시된 설계 방법과 절차에 대한 검증을 실험을 통해 입증하였다.

Key Words : Harmonics, Passive filter, Resonance, Power system, Nonlinear loads

\section{Introduction}

Harmonics are sinusoidal voltage or current waveforms having frequencies that are whole multiples of the frequency at which the supply system is designed to operate [1]. Generally, the power system voltage and current is assumed to be a pure sinusoid at a fundamental frequency $(50 \mathrm{~Hz}$ or $60 \mathrm{~Hz})$. The sinusoidal voltage applied to a nonlinear load result in non-sinusoidal waveforms (distorted waveforms) called "harmonics". Proliferation of power electronic loads in an electrical power system produces harmonics distortion as well as many other problems. In particular, motor drives among nonlinear loads produce a significant amount of harmonics during power-converting processing and induce many obstacles [2-5]. They reported harmonics cause fail of capacitor banks, overheating of transformers, breakers and fuses tripping, unreliable operation of electronic

*Corresponding Author : Jae-Gen Yoo

Tel: +82-31-580-3054 email: jgyoo@kesco.or.kr

Received September 24, 2012 Revised October 5, 2012

Accepted November 8, 2012 
equipment, meter error, communication interference and so on.

So, many standards related harmonics has been developed in order to limit emission of harmonics and to provide guidelines on harmonics. For example IEC 61000-3-2: 1998 outline the emission limits from equipment and IEEE 519: 1992 provides guidelines on harmonics only [6-7]. Especially, IEEE 519: 1992 standard helped the user keep the voltage and current harmonic within a proposed level.

Active and passive filters may be considered as concrete countermeasures to suppress harmonics [8-10]. Active filters, based on non-sinusoidal currents to meet the current harmonics have become an attractive harmonic countermeasure in recent years. However, the costs involved active filters are quite high. Passive filters, providing a shunt path of low impedance to the harmonic frequencies, generally experience many problems such as harmonic amplification and the fact that their performance is constantly dependent on system impedances [2, 11]. There is also the probability of generating series or parallel resonance with the power system [11]. These problems cause that the power system engineers and designers disregard the installation of passive filter to defeat harmonics in their power system. The ideal criterion and implementation of harmonic filter design is to eliminate all detrimental effects caused by waveform distortion. However, this ideal criterion is unrealistic because of technical and economical reasons. But it is proved that reasonably well designed passive filters are effective and suitable as a harmonic countermeasure, passive filters could be considered as a harmonic countermeasure on the market due to their lower cost.

This work introduces that passive filters are very available to defeat harmonic problems of the power system if passive filters are well designed. So, first of all, we describe the design method of harmonic passive filters. Next, we designed the passive filter for the power system having harmonic problems due to use of $100 \mathrm{HP}$ DC motor system, an extruding machine, an air blower and other loads. The designed passive filter is applied to the considered power system. Finally, the experimental results show the effect of the harmonic passive filter and verify passive filters could be considered as a harmonic countermeasure due to their low cost.

\section{Design method of passive filter}

A passive filter to suppress harmonics in the electrical power system is built using an array of capacitors, inductors, and resistors. It can take the form of a simple line reactor or may use a series of parallel resonant filters to eliminate harmonics. Passive filters are largely classified into a tuned filter to eliminate low order harmonics, and a high pass filter to eliminate high order harmonics (e.g. 17th up). The parameter to be considered prior to the selection of $\mathrm{R}, \mathrm{L}$ and $\mathrm{C}$ during passive filter design is the quality factor (Q) [2].

The quality factor determines the sharpness of tuning. In this respect filters may either be of high $\mathrm{Q}$ type or low $\mathrm{Q}$ type. The high $\mathrm{Q}$ type filter is sharply tuned to one of the lower harmonic frequencies and a typical value is between 30 and 60 . The low Q type filter, typically in the region of $0.5 \sim 5$, has low impedance over a wide range of frequencies [2].

The size of a harmonic passive filter is defined as the reactive power that the filter supplies at fundamental frequency. The ratings of the capacitors and reactors to be used as filter must be properly selected based on the technical parameters like as harmonic order to be removed, harmonic profile of the load current, reactive power requirements of the load, harmonic factor of neutral current, system data and configuration (i.e. power factor, one-line diagram). Moreover, a detailed power quality study would be necessary to assure that connection of the shunt passive harmonic filter will not cause a resonance condition on the power system. This is because harmonic resonance can result to the magnification of certain harmonic frequencies.

Figure 1 describes the design process of a harmonic passive filter used in this paper. First, we measured the harmonic current spectrum, voltage and current waveform and magnitude produced in the considered power system. Next, we determined the amount of harmonic current to be filtered and the size of the capacitor for the filters based on the required harmonic current rating and the fundamental frequency reactive power needed in the target power system. After determining the type of filter (tuned filter and high pass filter) according to harmonic order and magnitude, we determined the reactor impedance and rating to achieve the desired tuning, resistor value and 
quality factor (Q-factor) was calculated. Next we researched whether the compensated reactive power, harmonic limit of the power system and the voltage and current values of the passive filter are proper. Finally, the filter response, the effect of tolerances in the capacitor value and reactor value, the peak voltage across the capacitor and adverse interactions with the power system were checked.

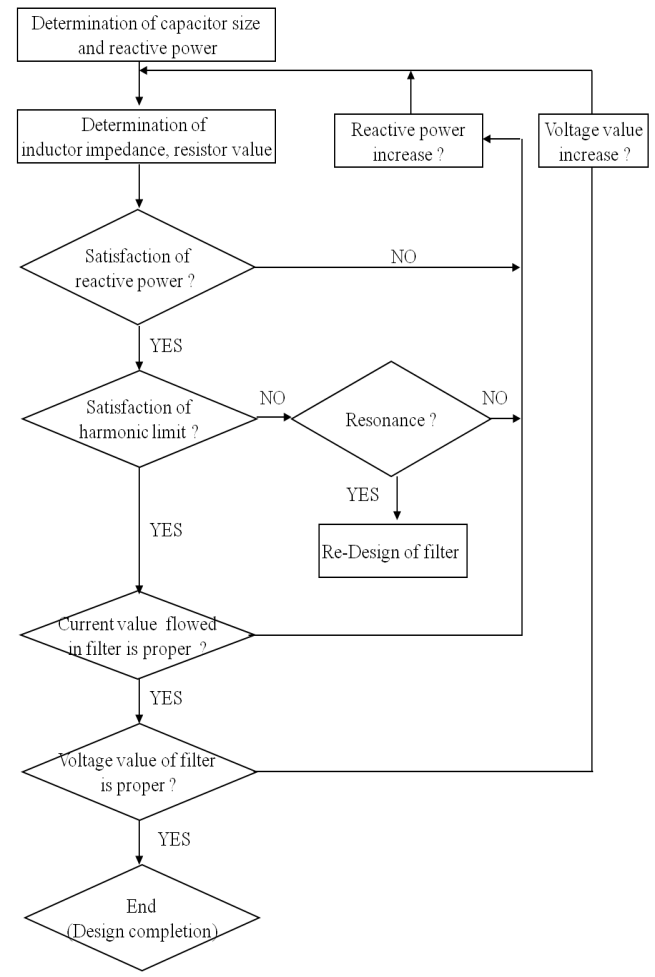

[Fig. 1] The design process of a harmonic passive filter

\section{Passive filter design}

In order to design and apply a passive filter, this paper considered the power system of Fig. 2. The power system used a 100HP DC motor to produce automobile soundproofing material and it was difficult to optimize effects of the passive filter due to repeated starts and stops of the DC motor, an extruding machine, an air blower and other loads.

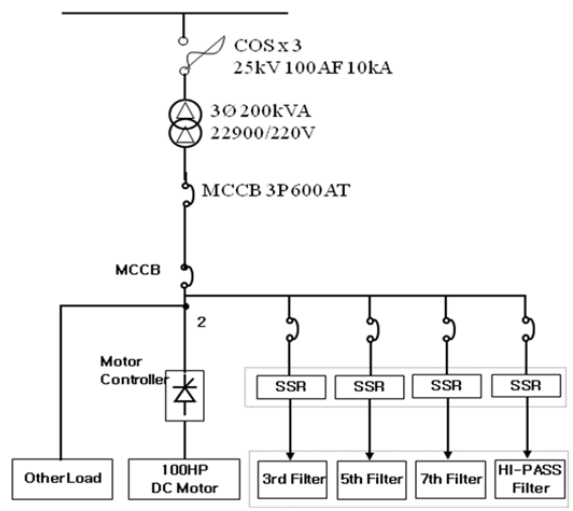

[Fig. 2] The wring diagram of the designed filter

Table 1 lists the design and production specifications of the passive filter for the considered power system. The passive filter consists of a tuned filter for the third, fifth, and seventh order and a high-pass filter for the 11th and high orders. The SSR (Solid State Relay) was used to switch each branch of the passive filter. Fig 3 shows the developed filter.

[Table 1] Specification of the passive filter

\begin{tabular}{|c|c|c|c|c|}
\hline Section & $\begin{array}{c}\text { Third } \\
\text { order }\end{array}$ & $\begin{array}{c}\text { Fifth } \\
\text { order }\end{array}$ & $\begin{array}{c}\text { Seventh } \\
\text { order }\end{array}$ & Hi-pass \\
\hline Capacitor(kVAR) & 6.1 & 5.7 & 5.5 & 10 \\
\hline Inductor (mH) & 2.6 & 0.95 & 0.4 & 0.09 \\
\hline
\end{tabular}

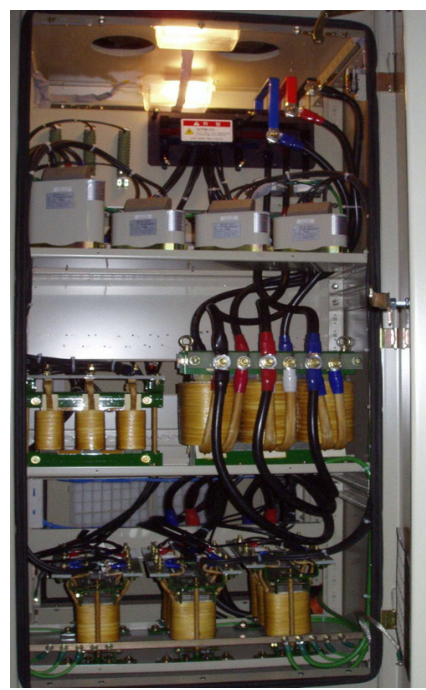

[Fig. 3] The designed passive filter 


\section{Experimental Results}

In order to verify the performance of designed filter, the field test has been carried out by installing the filter in the power system. Harmonic current contents and waveform were analyzed by using power quality analyzer (Model: HIOKI 3196 PQA). Figure 4 (a) and (b) indicate the voltage and current waveform and magnitude of each harmonic order (\%) without the passive filter in the considered power system. The current waveforms were distorted because of harmonic currents due to the DC motor drive and other loads. As shown in Fig. 4 (b), the content of $5^{\text {th }}$ harmonic currents is $23.05 \%$, and current THD is $25.08 \%$.

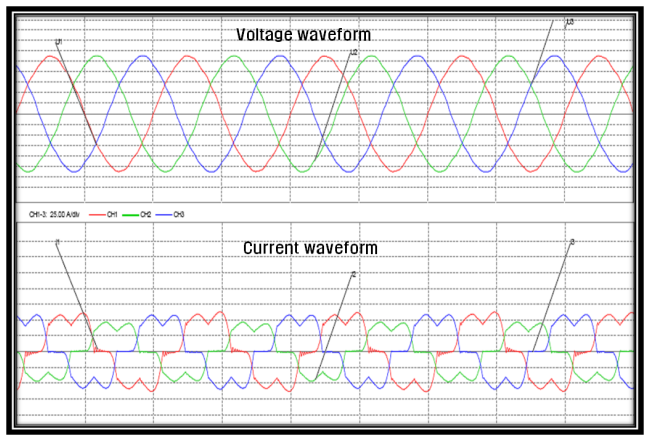

(a) Voltage and current waveform

\begin{tabular}{|c|c|c|c|c|c|}
\hline \multicolumn{6}{|c|}{ CH1 I VALUE iHarm OFF } \\
\hline Order & [\%] & Order & [\%] & Order & [\%] \\
\hline 1 & 100.00 & 18 & 0.02 & 35 & 0.57 \\
\hline 2 & 0.36 & 19 & 1.44 & 36 & 0.02 \\
\hline 3 & 1.96 & 20 & 0.01 & 37 & 0.53 \\
\hline 4 & 0.12 & 21 & 0.07 & 38 & 0.02 \\
\hline 5 & 23.05 & 22 & 0.02 & 39 & 0.09 \\
\hline 6 & 0.11 & 23 & 1.01 & 40 & 0.03 \\
\hline 7 & 7.10 & 24 & 0.01 & 41 & 0.49 \\
\hline 8 & 0.03 & 25 & 0.87 & 42 & 0.03 \\
\hline 9 & 0.18 & 26 & 0.02 & 43 & 0.50 \\
\hline 10 & 0.07 & 27 & 0.07 & 44 & 0.03 \\
\hline 11 & 4.94 & 28 & 0.03 & 45 & 0.12 \\
\hline 12 & 0.03 & 29 & 0.75 & 46 & 0.03 \\
\hline 13 & 3.06 & 30 & 0.02 & 47 & 0.49 \\
\hline 14 & 0.02 & 31 & 0.71 & 48 & 0.02 \\
\hline 15 & 0.10 & 32 & 0.01 & 49 & 0.52 \\
\hline 16 & 0.03 & 33 & 0.08 & 50 & 0.03 \\
\hline 17 & 1.68 & 34 & 0.02 & THD & $25.08[\%]$ \\
\hline \multicolumn{6}{|c|}{ tSt } \\
\hline
\end{tabular}

(b) Current Harmonic component

[Fig. 4] Without harmonic filter

Figure 5, 6 and 7 indicate the harmonic current waveform inputting in the $5^{\text {th }}, 7^{\text {th }}$ and high-pass filter after the developed harmonic filter installation. These waveforms mean that the each filter defeat harmonic content very well. Figure 8 (a) and (b) show three-phase voltage and current waveforms magnitude of each harmonic order (\%) measured by power quality analyzer in the power system with the designed filter respectively. Although it is not a perfect sine wave, the current waveforms of Figure 8(a) with passive filter are similar to a sine wave. And the $5^{\text {th }}$ harmonic current is decreased to $7.6 \%$ from $23.55 \%$, and the current THD is decreased to $8.06 \%$ from $25.08 \%$. The experimental results show the effect of a harmonic passive filter system and verify passive filters could be considered as a harmonic countermeasure due to their low cost although there is also the probability of generating series or parallel resonance with the power system.

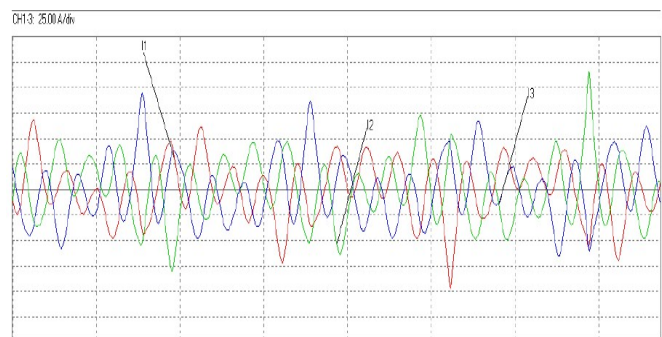

[Fig. 5] The harmonic current inputted 5th filter.

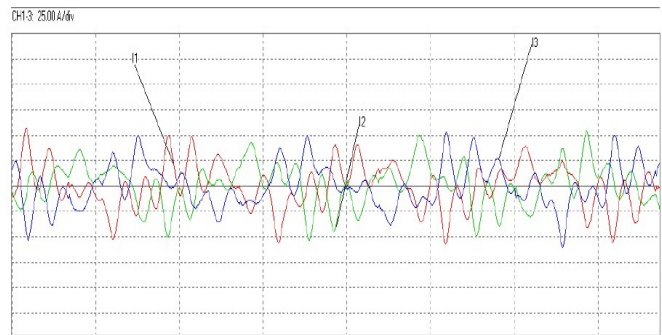

[Fig. 6] The harmonic current inputted 7th filter.

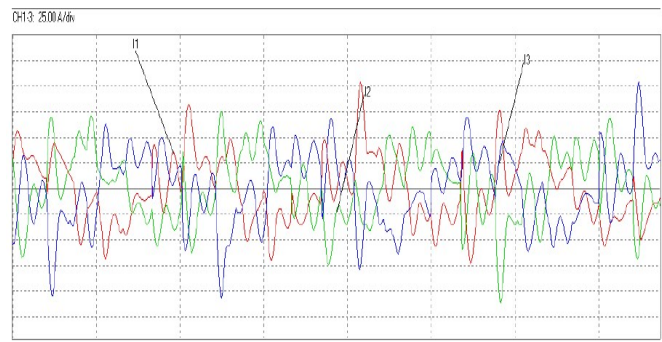

[Fig. 7] The harmonic current inputted high-pass filter 


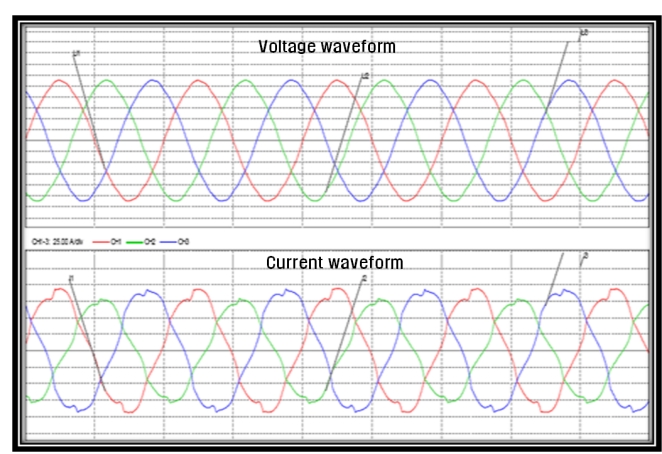

(a) Voltage and current waveform

\begin{tabular}{|c|c|c|c|c|c|}
\hline \multicolumn{6}{|c|}{ 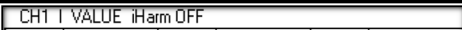 } \\
\hline Order & {$[\%]$} & Order & [\%] & Order & [\%] \\
\hline 1 & 100.00 & 18 & 0.01 & 35 & 0.20 \\
\hline 2 & 0.10 & 19 & 0.57 & 36 & 0.01 \\
\hline 3 & 2.30 & 20 & 0.01 & 37 & 0.11 \\
\hline 4 & 0.05 & 21 & 0.14 & 38 & 0.00 \\
\hline 5 & 7.16 & 22 & 0.01 & 39 & 0.06 \\
\hline 6 & 0.11 & 23 & 0.55 & 40 & 0.00 \\
\hline 7 & 1.17 & 24 & 0.01 & 41 & 0.17 \\
\hline 8 & 0.02 & 25 & 0.33 & 42 & 0.00 \\
\hline 9 & 0.37 & 26 & 0.01 & 43 & 0.08 \\
\hline 10 & 0.02 & 27 & 0.08 & 44 & 0.01 \\
\hline 11 & 2.08 & 28 & 0.00 & 45 & 0.07 \\
\hline 12 & 0.01 & 29 & 0.31 & 46 & 0.01 \\
\hline 13 & 0.65 & 30 & 0.00 & 47 & 0.15 \\
\hline 14 & 0.01 & 31 & 0.17 & 48 & 0.00 \\
\hline 15 & 0.29 & 32 & 0.01 & 49 & 0.07 \\
\hline 16 & 0.02 & 33 & 0.06 & 50 & 0.01 \\
\hline 17 & 1.03 & 34 & 0.01 & THD & $8.06[\%]$ \\
\hline \multicolumn{6}{|c|}{ No.1 10/04 09:45:18.144 Ext (Stop) } \\
\hline
\end{tabular}

(b) Current Harmonic component

[Fig. 8] After the passive filter installation

\section{Conclusion}

This work has presented the application of the harmonic passive filter with single-tuned and high-pass filters at the power system that use 100HP DC motor system, an extruding machine, an air blower and other loads. The experimental results show the effect of a harmonic passive filter system and verify passive filters could be considered as a harmonic countermeasure due to their low cost although there is also the probability of generating series or parallel resonance with the power system. In conclusion, passive filters could be considered as a harmonic countermeasure due to their lower cost and effect if filters are well designed. But although the passive filter is designed and produced by considering several conditions such as the harmonic field data, power system impedance, frequency fluctuation, filter size and target values of harmonic repression, the effects of the passive filter could be changed according to operating conditions of the loads. So, in order to increase the effect of passive filter, the system to monitor the performance of the implemented passive filter and control a passive filter according to operating conditions of harmonic loads and harmonic magnitude and reactive power will be developed and applied.

\section{References}

[1] J. Arrillaga, N. R. Waston, and S. Chen, "Power System Quality Assessment”, WILEY, 2001.

[2] J. Arrillaga, D. A. Bradley, and P.S. Bodger, "Power System Harmonics", John Willy \& Sons, 1985.

[3] IEEE Task Force, "Effects of harmonics on equipment", IEEE Transactions on Power Delivery, Vol. 8, No. 2, pp. 672-680, April 1993.

[4] Chih-Jn Chou, Chih-Wen Liu, June-Yown Lee, and Kune-Da Lee, "Optimal Planning of Large-HarmonicFilters Set at High Voltage Level", IEEE Transactions on Power Systems, vol. 5, no. 1, pp. 433-441, February 2000.

[5] IEEE Working Group on Power System Harmonics, "The effects of power system harmonics on power system equipment and loads", IEEE Transactions on Power Apparatus and Systems, vol. PAS-104, no. 9, pp. 2555-2563, 1985

[6] IEC 61000-3-2 : 1994, "Electromagnetic Compatibility (EMC), Part 3, section 2 and section 3.

[7] IEEE Std. 519-1992, "IEEE Recommended Practices and Requirements for Harmonic Control in Electric Power Systems".

[8] Yokihiko Sato, Takeshi kawase, Masamitsu Akiyama, and Teruo Kataka, "A Control Strategy for General-Purpose Active Filters Based on Voltage Detection", IEEE Transactions on Industry Application, vol. 36, no. 5, pp. 1405-1412, October 2000.

[9] Tein-Ting Chang and Hong-Chan Cang, "An Efficient for Reducing Harmonic Voltage Distortion in Distribution Systems with Active Power Line Conditioners", IEEE Transactions on Power Delivery, Vol. 15, No. 3, pp. 990-995, July 2000

[10] Fang Z. Peng, "Harmonic Sources and Filtering Approaches", IEEE Industry Application Magazine, pp.18-24, August 2001 
[11] C. J. Wu, J. C. Chiang, S. S. Yen, C. J. Liao, J. S. Yang, and T. Y. Guo, "Investigation and Mitigation of Harmonic amplification problems caused by single-tuned filters", IEEE Transactions on Power Delivery, vol. 13, no. 3, pp. 800-806, July 1998.

Jeong-Chay Jeon

[Regular member]

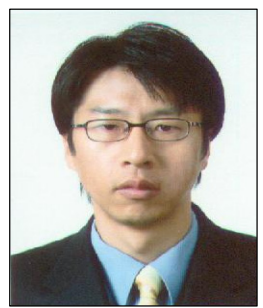

- Feb. 1999 : Wonkwang Univ., Electrical Engineering, MS

- March. $2000 \sim$ current : Electrical Safety Research Institute, senior researcher

$<$ Research Interests $>$

Measurement and control system, Power quality, intelligent control and embedded systems

\section{Jae-Hyun Kim}

[Regular member]

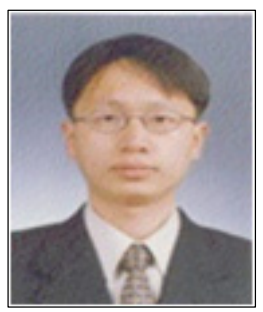

- Feb. 2001 : Kyungpook Univ., Electronic Engineering, MS

- March. $2001 \sim$ current : Electrical Safety Research Institute, researcher
Jae-Geun Yoo

[Regular member]

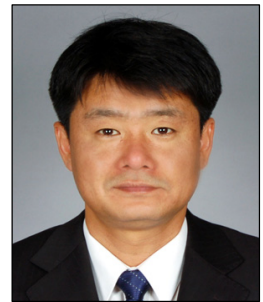

- Feb. 1991 : Konkuk Univ., Electrical Engineering, MS

- Feb. 2007 : Konkuk Univ., Electrical Engineering, $\mathrm{PhD}$

- Feb. $1992 \sim$ March. 1996 : Daewoo Electronics, researcher

- April. $1996 \sim$ current : Electrical Safety Research Institute, Director

$<$ Research Interests $>$

Pwer quality, control and embedded systems

$<$ Research Interests $>$

Electrical safety protection system 